\title{
Justiça, Judiciário e política no México
}

Justice, judiciary and politics in Mexico

Justicia, Poder Judicial y política en México

\section{Lígia Mori Madeira' ${ }^{1}\left[\right.$ \& Andrés del Río ${ }^{2}$}

Na última década, os estudos sobre Poder Judiciário e sistema de justiça foram multiplicando-se na América Latina. Essa proliferação teve seu desenvolvimento administrado pelas velocidades e características específicas de cada país, a partir de demandas das realidades políticas e conjunturais, mas é notório o seu avanço na ciência política, em que esses trabalhos vêm-se consolidando, rompendo com uma tradição de trabalhos historicamente dominados pelo direito, com estética, metodologia e, até mesmo, léxico próprios. Tais pesquisas, que, pouco saíam das fronteiras jurídicas, foram diversificando-se e dialogando cada vez mais com outras áreas do conhecimento humano: antropologia do direito, sociologia jurídica, história, entre outras disciplinas que começaram a criar pontes e diálogos, fortalecendo a investigação sobre o judiciário e sistema de justiça. A ciência política tem sido responsável também

Professora Associada do Departamento de Ciência Política da Universidade Federal do Rio Grande do Sul (UFRGS), Porto Alegre, RS, Brasil. E-mail: <ligia.madeira@ufrgs.br>

2 Professor Adjunto e Chefe de Departamento de Geografia e Políticas Públicas IEAR, da Universidade Federal Fluminense (UFF), Niterói, RJ, Brasil. E-mail: <andresdelrio@id.uff.br> 
pela abertura de diversos debates teóricos, metodológicos, além de impulsionar desafios empíricos e de pesquisa comparada.

O livro Gobierno y política judicial en México, organizado por Azul Aguiar e publicado pela Editorial Fontamara, é um exemplo acabado dessa nova fase, revelando uma contribuição importante à área dos estudos judiciais. Embora olhe para o caso do México, a obra tem fôlego para se tornar uma grande referência de política judicial. Consegue, de forma bem-sucedida, sistematizar a discussão teórica produzida pela ciência política a respeito do sistema de justiça, exibindo trajetórias e expondo realidades e percepções com rigor e consistência metodológica. Seu primeiro grande mérito é, portanto, unir perspectivas teóricas e metodológicas da ciência política sem perder o diálogo com o âmbito e a narrativa jurídica.

O livro ajuda a compreender a trajetória de uma área cujas controvérsias sempre estiveram postas. Se, nas primeiras análises, esperava-se que os tribunais poderiam contribuir com a garantia de direitos, sendo a conhecida judicialização uma possibilidade de emancipação a partir do direito, a realidade que se coloca hoje para nossas sociedades latino-americanas é novamente perguntar qual o papel dos judiciários na manutenção ou suporte a Estados autoritários, os quais iniciam uma nova onda após períodos de estabilidade democrática e guinadas à esquerda.

A obra aborda, em seu conjunto, três temas fundamentais para compreendermos os desdobramentos da relação entre justiça, judiciários e política: direitos humanos; tribunais e sua organização; e reformas penais. Mas não se restringe a eles, levando em consideração a atuação judicial como judicial policy, ou seja, judiciários que participam do ciclo de políticas públicas incidindo para além da implementação, em fases como a agenda e a formulação.

Conta com quatro capítulos escritos por pesquisadores com reconhecida trajetória na área, que dialogam entre si em harmonia, pintando um quadro geral ao descrever e explicar a situação do caso do México. Há um elemento inovador adicional: interessantes e extensas entrevistas fecham o livro, trazendo a percepção das dificuldades, das limitações, dos horizontes e da complexidade da área. 
Reforçando o perfil pedagógico do volume e a preocupação com leitores iniciantes (ou já especializados), o livro traz uma extensa bibliografia sistematizada sobre os estudos mais relevantes publicados sobre o judiciário, outro ponto alto da obra. Faz-se importante salientar, porém, que essa bibliografia é dominada por um perfil teórico hegemônico, pouco diverso em sua visão de mundo e na compreensão do papel do judiciário na sociedade.

Sintetizamos, a seguir, de forma breve, cada parte do livro.

O capítulo de Azul Aguiar apresenta os principais enfoques por meio dos quais as análises de política judicial vêm sendo feitas: legalista, atitudinal-ideológica, estratégico ou neoinstitucionalista de escolha racional e ideacional. Trata-se de um estudo no qual a trajetória da discussão de judicial politics é materializada.

No segundo texto, Júlio Rios-Figueroa analisa os conselhos da judicatura e o papel que esses têm (ou não) no controle dos juízes mundo afora, expondo os conselhos da magistratura precursores, chegando-se, enfim, às especificidades institucionais latino-americanas e do conselho do México.

Já Karina Ansolabehere investiga a militância dos juízes ao interpretar temas de direitos humanos, analisando e questionando o ativismo judicial pró-direitos, demonstrando a sua imbricação com variáveis, de ordem interna e externa, como a cultura jurídica, os interesses dos juízes, as relações entre a Suprema Corte e os tribunais inferiores, a estrutura do litígio e a visibilidade do caso, bem como com aspectos relativos ao desenho constitucional e ao sistema de acesso à justiça. A segunda parte do trabalho busca analisar os efeitos do ativismo judicial pró-direitos, em dois dos principais temas caros à América Latina: justiça transicional e pós-conflito, além da extensão a direitos econômicos e sociais (SER).

Matt Ingram, por sua vez, debruça-se sobre as reformas do processo penal no México, fazendo uma análise de mudança institucional, revisando essa literatura e ilustrando a trajetória da reforma penal no México, tendo como pano de fundo uma análise de ciclo de política pública. 
Como foi salientado, o ponto alto são as entrevistas com três dos autores, que permitem ao leitor compreender como os pesquisadores utilizam e adequam a literatura internacional à realidade latino-americana; as possibilidades e dificuldades dessas análises, bem como a grande lista de referências que permitem ao leitor uma incursão nesse debate.

O livro nos deixa com vontade de conhecer mais sobre a dinâmica mexicana e outras problemáticas existentes, mas ausentes no volume, como análises históricas sobre tribunais superiores, os desafios e as dinâmicas do federalismo mexicano e as relações com o sistema de justiça; as dinâmicas internas da instituição no processo de decisão, entre outras. Sem dúvida, uma análise comparada com outros casos latino-americanos colaboraria ainda mais para uma percepção aprofundada dos limites e desafios do caso mexicano.

Certamente, pela abertura à discussão e as expectativas trazidas com ela, figurará como literatura obrigatória a todos aqueles que buscam compreender melhor os meandros entre justiça e política, tema cada vez mais importante para a ciência política contemporânea. Em um momento em que os judiciários e seus agentes aparecem mais nas notícias que atores de relevância da política nacional, conhecer mais sobre esse poder que sempre esteve nas sombras é abrir uma caixa de pandora, a qual permite compreender melhor tanto a dinâmica de nossas instituições quanto o funcionamento das nossas democracias.

\section{Referência}

AGUIAR, Azul America (org.). Gobierno y política judicial en México. México, D.F.: Editorial Fontamara, 2019. 217p.

Recebido em 07 de novembro de 2019 Aprovado em 09 de setembro 2020 